\title{
PENGAKUAN IDENTITAS WARIA DI INDONESIA (STUDI KASUS WARIA YANG BERHADAPAN DENGAN HUKUM DI YOGYAKARTA) ${ }^{1}$
}

\author{
Fardi Prabowo Jati*, Cucu Mukhosiyah, Hanifah Febriani \\ Fakultas Hukum Universitas Gadjah Mada \\ Jalan Socio Yusticia No. 1 Bulaksumur Yogyakarta - Indonesia 55281 \\ fardi.prabowo.88@gmail.com
}

\begin{abstract}
Although waria have not classified as mental disorders and have sociocultural contributions in society, yet this community still has its vulnerabilities including when waria in conflict with the law. Therefore, this study aims to discuss two things. First, the recognition of transgender identity in Indonesian laws and regulations. Second, the recognition of the identity of waria in the case of waria in conflict with the law in Yogyakarta. This research is an empirical normative juridical research. The result is that there is already recognition in international conventions. Nevertheless, in Indonesian law there is still discrimination over the identity and characteristics inherent in waria. In some cases in Yogyakarta, waria's identity and characteristics have been accepted by law enforcement officials, although not yet fully.
\end{abstract}

Keywords: Waria; Come in Conflict with the Law; Gender and Sexuality Diversity.

\begin{abstract}
Abstrak
Kendati waria sudah tidak digolongkan sebagai gangguan jiwa dan memiliki kontribusi sosiakultural di masyarakat, faktanya komunitas ini masih memiliki kerentanannya. Kerentanan tersebut termasuk ketika waria berhadapan dengan hukum. Oleh karena itu penelitian ini mencoba membahas dua hal. Pertama, pengakuan identitas waria dalam peraturan perundangundangan di Indonesia. Kedua, pengakuan identitas waria dalam kasus waria berhadapan dengan hukum di Yogyakarta. Penelitian ini merupakan penelitian yuridis normatif empiris. Hasil penelitian ini menunjukkan sudah ada pengakuan dalam konvensi internasional. Meskipun demikian, dalam hukum Indonesia masih terdapat diskriminasi atas identitas dan karakteristik yang melekat terhadap waria. Dalam beberapa kasus waria yang berhadapan dengan hukum, waria sudah diterima identitas dan karakteristiknya oleh aparat penegak hukum meskipun belum sepenuhnya.
\end{abstract}

Kata Kunci: Waria; Berhadapan dengan Hukum; Keragaman Gender dan Seksualitas.

\footnotetext{
${ }^{1}$ Hasil penelitian ini didanai oleh Unit Riset dan Publikasi Fakultas Hukum Universitas Gadjah Mada tahun 2020. Penelitian dilaksanakan dalam rangka progam hibah penelitian mahasiswa.
} 


\section{A. Pendahuluan}

Eksistensi waria sudah ada sejak dulu di Indonesia Keberadaan waria sudah dapat dilihat di berbagai aktivitas sosial ekonomi maupun kebudayaan di berbagai daerah di Indonesia dengan sebutan yang beragam. Di daerah Jawa, Bali, dan Sulawesi dikenal istilah kedi, di Makassar dan masyarakat bugis dikenal dengan istilah kawe-kawe, di jawa dan Sulawesi juga dikenal istilah wandu, dan di kebudayaan suku Bugis mengenal istilah calabai untuk merujuk pada identitas waria.(Boellstorff, 2004). Bahkan Ali Sadikin pada saat menjabat sebagai Gubernur Jakarta Raya pada tahun 1969 memfasilitasi pembentukan Himpunan Wadam Djakarta yang kemudian pada sekitar tahun 1980-an istilah wadam berganti nama dengan sebutan waria. Perkembangan selanjutnya waria kerap disebut dengan sebutan transpuan seiring berkembangnya wacana tentang transgender di Indonesia.

Kendati keberadaannya sudah ada sejak dulu, waria kerap menjadi korban kekerasan dan mendapatkan hukuman karena dianggap melanggar konsepsi peran gender yang dikontruksikan oleh mayoritas masyarakat. Selain itu, waria muda termasuk dalam kelompok yang sangat rentan dan termarjinalkan di dalam masyarakat (O'Flaherty, 2015). Pada April 2020 di Cilincing, Jakarta Utara, seorang waria dibakar oleh sedikitnya enam preman setelah dituduh mencuri telepon genggam (Amali, 2020). Banyak pihak mengecam tindakan aparat kepolisian karena menetapkan para pelaku pembunuhan waria tersebut hanya dengan ketentuan pasal pengeroyokan yang mengakibatkan kematian. Selain itu, ada kasus dimana polisi kebingungan saat ingin menempatkan seseorang yang telah mendapatkan penetapan pengadilan untuk mengganti jenis kelaminnya menjadi perempuan dalam sel tahanan (Briantika, 2020). Privasi orang tersebut kemudian dilanggar dan menjadi bahan perundungan di media sosial.

Secara umum waria adalah seorang individu yang memiliki tubuh laki-laki dan berjiwa perempuan (Blackwood, 2005). Dari hasil penelitian Boellstorff, waria di Indonesia dilihat bukan sebagai gender ketiga tapi memiliki kecenderungan pada pemahaman seorang laki-laki yang memiliki sifat sfat perempuan. Dalam berhubungan seks, waria tidak selalu berperan sebagai pihak yang dipenetrasi melainkan juga ada yang melakukan penetrasi terhadap laki-laki. Hal itu menjadi salah satu alasan waria tidak melakukan operasi penggantian kelamin karena ada laki-laki yang masih mengharapkan waria memiliki penis (Boellstorff, 2004). Menurut The Diagnostic and Statistical Manual of Mental Disorders edisi kelima identitas waria (transgender) itu sendiri maupun homoseksualitas bukan lagi sebagai gangguan jiwa.

Dalam Prinsip-Prinsip Yogyakarta memberikan pengertian tentang konsep orientasi seksual dan identitas seksual sebagai hak yang dimiliki setiap manusia yang tidak boleh didiskriminasikan dan dilanggar (Team, 2006). Orientasi seksual diartikan sebagai ketertarikan seseorang baik secara emosional, kasih sayang, intim, maupun sexual terhadap orang lain dengan gender yang berbeda atau yang sama dengan dirinya atau dengan lebih dari satu gender. Sementara identitas gender ialah perasaan mendalam setiap orang dan pengalaman individu tentang gendernya yang mungkin sesuai atau tidak sesuai dengan jenis kelamin yang ditetapkan sejak lahir, termasuk perasaan pribadi tentang tubuhnya (yang mungkin dapat dipilih secara bebas atau diubah dengan intervensi secara medis) dan juga termasuk ekspresi gender yang meliputi pakaian, ucapan, dan tingkah laku. John P.J Pinel dari hasil penelitiannya menunjukan bahwa orientasi seksual dan identitas seksual adalah dua hal yang tidak berhubungan satu sama lain (Pinel, 2009). Oleh karena itu, waria bisa saja memiliki orientasi seks dengan laki-laki, perempuan, identitas gender yang lain, atau tidak memiliki orientasi seksual (aseksual).

Sejauh ini belum ada penelitian yang secara khusus membahas tentang waria yang berhadapan dengan hukum, baik sebagai 
saksi, korban, maupun pelaku. Penelitian yang berjudul, "Hak Asasi Manusia LGBT Dalam Kebijakan Dalam Negeri Indonesia" mengulas tentang berbagai peraturan perundang-undangan baik ditingkat lokal maupun nasional yang memuat ketentuan diskriminatif terhadap komunitas LGBT secara umum di Indonesia (Muthmainnah, 2015). Penelitian yang berjudul "Politik Subaltern : Pergulatan Identitas Waria" mengulas tentang dinamika pengorganisasian waria dalam memperjuangkan identitas waria di Yogyakarta (Widayanti, 2009). Penelitian yang berjudul "Playing back the nation: Waria, Indonesian Transvestites" membahas pengakuan identitas waria di Indonesia dalam realitas sosial budaya di berbagai wilayah Indonesia (Boellstorff, 2004).

Penelitian ini bertujuan untuk membahas dua hal. Pertama, untuk mengetahui bagaimana pengakuan waria di dalam ketentuan peraturan perundangundangan di Indonesia. Dalam hal ini pengakuan dimaknai sebagai legitimasi status hukum dalam berbagai peraturan perundang-undangan di Indonesia. Kedua, untuk mengetahui bagaimana pengakuan waria dalam kasus waria yang berhadapan dengan hukum. Oleh karena tujuan ini melihat fenomena praktik di lapangan, pengakuan dimaknai sebagai penerimaan identitas gender waria yang dilakukan aparat penegak hukum dalam kasus waria yang berhadapan dengan hukum. Penelitian ini menjadi penting karena selama ini belum ada yang secara khusus membahas tentang dinamika pengakuan identitas waria di dalam ketentuan peraturan perundangundangan di Indonesia. Selain itu, kajian tentang waria yang berhadapan dengan hukum di Indonesia juga masih sangat minim. Oleh karena itu, pembahasan praktek yang selama ini terjadi pada kasus waria yang berhadapan dengan hukum dapat menjadi kebaruan dalam kajian waria di Indonesia.

\section{B. Metode Penelitian}

Metode yang digunakan dalam penelitian ini bersifat normatif empiris. Penelitian hukum normatif empiris ini meneliti pemberlakuan ketentuan hukum normatif secara in action pada setiap peristiwa hukum yang terjadi dalam masyarakat. Perpaduan penelitian hukum normatif empiris ini menggunakan data berbentuk data primer dan data sekunder. Data primer diperoleh secara langsung berupa keterangan-keterangan dari para responden dan kenyataan-kenyataan yang ada di lapangan melalui FGD, wawancara serta observasi lapangan. Penelitian ini menerapkan metode in-depth interview. FGD dilaksanakan dengan mengundang tiga organisasi besar waria di Yogykarta, yaitu Ikatan Waria Yogyakarta, Pondok Pesantren Waria Al-Fatah Yogyakarta, dan LSM Keluarga Besar Waria Yogyakarta. Dari hasil FGD tersebut, ditemukan narasumber yang pernah berhadapan dengan hukum yang bisa dilakukan wawancara.

Sedangkan data sekunder adalah data yang diperoleh dari studi kepustakaan dan bahan hukum. Data sekunder menelaah hal yang bersifat teoritis yang menyangkut asasasas hukum, konsepsi hukum, doktrindoktrin hukum, peraturan serta sistem hukum. Data sekunder digunakan sebagai referensi dan data tambahan untuk menjawab rumusan masalah. Data dikelompokkan, diolah dan dianalisis menggunakan metode kualitatif. Batasan dan ruang lingkup penelitian ini adalah waria yang berkonflik dengan hukum pidana, dengan lokasi penelitian di Daerah Istimewa Yogyakarta.

\section{Hasil dan Pembahasan}

\section{Pengakuan Identitas Waria Dalam Peraturan Perundang-undangan di Indonesia}

Pernyataan atau rekomendasi pertama yang memberikan perhatian secara khusus pada perlindungan berbasis orientasi seks dan identitas gender yang tidak biner termaktub dalam Prinsip-Prinsip 
Yogyakarta. Prinsip-Prinsip Yogyakarta dibentuk oleh para pakar HAM di seluruh dunia. Dokumen tersebut disebut sebagai pernyataan paling berpengaruh dalam wacana hukum HAM internasional yang mewajibkan negara untuk melakukan atau tidak melakukan dalam rangka promosi dan perlindungan terhadap hak orang dengan keberagaman orientasi seksual dan identitas gender serta terhadap orang dengan kondisi intersex (O'Flaherty, 2015). Prinsip-prinsip Yogykarta kemudian banyak dikutip di forum forum resmi PBB, Uni Eropa, dan Afrika Selatan, serta dijadikan rujukan bagi masyarakat sipil dalam melakukan advokasi.

International Covenant on Civil dan Political Right (ICCPR) dan International Convenant on Economic, Social, and Cultural Right (ICESR) tidak secara eksplisit menyebut orientasi seksual dan identitas seksual sebagai bagian dari HAM. Kendati demikian, Human Right Committee (HRC) menyebut bahwa diskriminasi berdasarkan orientasi seksual dan identitas seksual dilarang berdasarkan ketentuan ICCPR (Petrova, 2013). Selain itu, Committee on Economic, Social, and Cultural Right (CESCR) juga telah menaruh perhatian pada orientasi seks dan identitas gender dalam pemenuhan hak ekosob. Perkembangan selanjutnya, komentar umum terkait ICESR telah dikeluarkan yang menyebut bahwa orientasi seks dan identitas gender termasuk status yang lain yang tidak boleh mendapatkan diskriminasi dalam memperoleh hak ekonomi, sosial, dan budaya.

Pada prinsipnya Undang-Undang Dasar Indonesia telah memberikan pengakuan terhadap HAM. Indonesia telah mengesahkan Undang-Undang Nomor 11 Tahun 2005 Tentang Pengesahan International Covenant On Economic, Social and Cultural Rights (kovenan internasional tentang hak-hak ekonomi, Sosial, dan Budaya) dan Undang-Undang Nomor 12 Tahun 2005 Tentang Pengesahan International Covenant on Civil and Political Rights (Kovenan Internasional Tentang Hak-Hak Sipil dan Politik). Dari dua undang-undang ratifikasi tersebut, maka pemerintah Indonesia harus melaksanakan ketentuan yg diatur dalam konvensi yang diratifikasi. Berdasarkan teori dualisme yang menyatakan bahwa hukum internasional dapat efektif diimplementasikan apabila telah ditransformasikan ke dalam hukum nasional (Sefriani, 2010). Dalam hal ini, ICCPR dan ICESR baru ditranformasikan secara formal. Akan tetapi dalam kasus waria yang berhadapan dengan hukum, Indonesia belum melakukan tranformasi secara subtansial berkaitan dengan pengakuan keragaman orientasi seks dan identitas gender.

Klausul dalam Pasal 28 J Ayat (2) Undang-Undang Dasar Negara Republik Indonesia Tahun 1945 kerap digunakan untuk menjustifikasi pembatasan atau diskriminasi terhadap waria yang dinilai bertentangan dengan nilai moral dan agama. Ketentuan tersebut menyatakan :

Dalam menjalankan hak dan kebebasannya, setiap orang wajib tunduk kepada pembatasan yang ditetapkan dengan undang-undang dengan maksud semata-mata untuk menjamin pengakuan serta penghormatan atas hak dan kebebasan orang lain dan untuk memenuhi tuntutan yang adil sesuai dengan pertimbangan moral, nilai-nilai agama, keamanan, dan ketertiban umum dalam suatu masyarakat demokratis.

Undang-Undang Nomor 39 Tahun 1999 tentang Hak Asasi Manusia tidak secara spesifik menyebut tentang hak kebebasan memilih identitas seksual. Pasal 1 angka (3) menyebut :

Diskriminasi adalah setiap pembatasan, pelecehan, atau pengucilan yang langsung ataupun tak langsung didasarkan pada pembedaan manusia atas dasar agama, suku, ras, etnik, kelompok, golongan, status sosial, status ekonomi, jenis kelamin, bahasa, keyakinan politik, yang berakibat pengurangan, penyimpangan atau penghapusan pengakuan, pelaksanaan 
atau penggunaan hak asasi manusia dan kebebasan dasar dalam kehidupan baik individual maupun kolektif dalam bidang politik, ekonomi, hukum, sosial, budaya, dan aspek kehidupan lainnya.

Dari pemaparan diskriminasi di atas, salah satu istilah yang digunakan dalam menjabarkan hal yang tidak boleh didiskriminasikan adalah jenis kelamin. Istilah jenis kelamin terlalu sempit karena hanya merujuk pada laki-laki dan perempuan. Jenis kelamin tersebut hanya didasarkan pada karakteristik sex yang dimiliki seseorang apakah memiliki penis atau vagina. Padahal organ genital mungkin tidak relevan dengan identitas seksualnya (Blackwood \& Johnson, 2012). Perbedaan jenis kelamin yang hanya didasarkan pada karakteristik yang biner tersebut menafikan keberadaan identitas seksual waria yang tidak memenuhi standar biner laki-laki dan perempuan. Selain itu, perlindungan diskriminasi berdasarkan orientasi seks juga tidak diatur dalam UU No.39 tahun 1999. UU tersebut tidak mengakui keberadaan identitas seksual waria yang kerap mendapat diskriminasi berdasar identitas dan orientasi seksual.

Undang-undang pertama yang mengaburkan makna orientasi seksual dengan perilaku seksual yang menyimpang adalah UU Nomor 44 Tahun 2008 tentang Pornografi. Undang-undang tersebut tidak secara langsung mendiskriminasikan waria, namun berdampak terhadap waria. Hal tersebut dikarenakan gender waria hanya dilihat pada saat lahir yaitu sebagai laki-laki. Sehingga waria yang berhubungan seksual dengan laki-laki akan dipandang sebagai homoseksual. Penjelasan Pasal 4 huruf a UU No. 44 Tahun 2008 mengartikan bahwa lesbian dan homoseksual termasuk dalam persenggamaan yang menyimpang yang dilarang secara eksplisit termuat dalam konten pornografi.

UU No. 44 Tahun 2008 pernah diujikan ke Mahkamah Konstitusi (MK). MK menolak seluruh permohonan dari pemohon pengujian materi UU No.44 Tahun 2008.
Kendati demikian, dalam Putusan Mahkamah Konstitusi Nomor 10-1723/PUU-VII/2009 hakim konstitusi Maria Farida menyampaikan pendapat berbeda (dissenting opinion). Maria Farida berpendapat bahwa permohonan harus dikabulkan. Salah satu pertimbangannya adalah :

Penjelasan tentang lesbian dan homoseksualitas sebagai suatu persanggamaan yang menyimpang adalah tidak sesuai dengan pandangan Organisasi Kesehatan Dunia (WHO) pada 17 Mei 1990 dan buku Pedoman Penggolongan dan Diagnosis Gangguan Jiwa di Indonesia, Edisi II, Departemen Kesehatan Republik Indonesia, tahun 1983 (PPDGJ II) dan (PPDGJ III) 1983.

Pertimbangan salah satu hakim konstitusi tersebut memberikan pengakuan bahwa homoseksualitas adalah bukan penyimpangan. Oleh karena itu, secara tidak langsung, salah satu karakteristik dari identitas waria sudah diakui. Pertimbangan hakim konstitusi Maria Farida tidak mendapat dukungan oleh hakim konstitusi yang lain, sehingga pengakuan tersebut tidak memiliki kekuatan hukum mengikat.

Hingga sekarang tidak ada ketentuan yang melakukan kriminalisasi atas dasar identitas seksual sebagai waria. Pasal 292 KUHP menyatakan, "Orang dewasa yang melakukan perbuatan cabul dengan orang lain sesama kelamin, yang diketahuinya atau sepatutnya harus diduganya belum dewasa, diancam dengan pidana penjara paling lama lima tahun." Kendati kriminalisasi perbuatan kekerasan seksual (cabul) sesama jenis terhadap anak diatur secara khusus, KUHP tidak melakukan kriminalisasi terhadap perbuatan sex sesama jenis kelamin konsensual antara orang yang sudah dewasa dan tidak terikat dalam hubungan perkawinan.

Di dalam naskah akademik RUU KUHP disebutkan bahwa salah satu hal-hal baru yang telah disarankan untuk dimasukkan dalam tindak pidana kesusilaan adalah 
melakukan perbuatan cabul dengan jenis kelamin yang sama antara sesama orang dewasa (BPHN, 2015). Kriminalisasi terhadap perbuatan cabul sesama jenis diformulasikan dalam Pasal 420 RUU KUHP. Ketentuan tersebut mengakui adanya perilaku homoseksual yang terjadi dimasyarakat. Ketentuan tersebut dapat menyasar terhadap waria yang belum mengganti jenis kelaminnya di pengadilan dan memiliki orientasi seks dengan laki-laki.

Pada tahun 2016, ketentuan dalam pasal 292 KUHP diujikan ke Mahkamah Konstitusi. Pemohon meminta Mahkamah Konstitusi untuk memperluas ketentuan pasal 292 KUHP sehingga juga mencakup hubungan seksual sesama jenis antara orang dewasa. Majelis hakim menolak permohonan para pemohon untuk seluruhnya. Dalam Putusan Mahkamah Konstitusi Nomor 46/PUU-XIV/2016 Mahkamah berpendapat bahwa perluasan pasal 292 KUHP tidak dapat diterima karena menimbulkan perbuatan pidana baru, yaitu perbuatan cabul sesama jenis terhadap orang dewasa. Oleh karena itu, langkah yang ditempuh seharusnya melalui mekanisme legislasi oleh DPR dan Pemerintah sebagai pembentuk undang-undang.

Ada empat hakim konstitusi yang menyampaikan pendapat berbeda (dissenting opinion) dalam pengujian pasal 292 KUHP ini, yaitu Arief Hidayat, Anwar Usman, Wahiduddin Adam, dan Aswanto. Mereka berpendapat bahwa praktik homoseksual merupakan perbuatan yang sangat tercela menurut hukum agama dan sinar ketuhanan serta nilai-nilai hukum yang hidup di masyarakat. Oleh karena itu, frasa "dewasa", "belum dewasa", "yang diketahui atau sepatutnya harus diduganya belum dewasa" dalam Pasal 292 KUHP harus dinyatakan bertentangan dengan UUD 1945 dan tidak mempunyai kekuatan hukum mengikat.

Dari beberapa peraturan yang ada termasuk di dalamnya bidang pengaturan hukum privat keperdataan, juga tidak ditemukan pengaturan yang secara jelas mengatur perlindungan ataupun pengakuan waria pada sistem hukum indonesia. Hukum keperdataan hanya mengakui bentuk seksualitas pria dan wanita, misalnya saja pada perkawinan maupun waris. Pengakuan sebatas laki-laki dan perempuan saja, hal ini terlihat pada maksud perkawinan menurut Pasal 28 BW menghendaki adanya persetujuan bebas dari calon suami dan calon istri. Pasal $27 \mathrm{BW}$ hanya menyebut perikatan antara seorang laki-laki dengan satu orang perempuan saja begitu pula sebaliknya.

Pada era soeharto dikhususkan kembali mengenai pengaturan kawin di indonesia sehingga lahir Undang-Undang Nomor 1 tahun 1974 dan telah direvisi menjadi Undang-Undang Nomor 16 tahun 2019 tentang perkawinan. Menurut Pasal 1 UU No. 1 Tahun 1974, "perkawinan adalah ikatan batin antara seorang pria dengan seorang wanita...", dengan demikian UU ini tidak mengakui adanya identitas gender selain pria dan wanita untuk melangsungkan pernikahan yang sah. Secara tidak langsung juga hanya mengakui bahwa pernikahan di indonesia merupakan pasangan yang heteroseksual saja. Apabila dianalisis lebih lanjut, pernikahan menurut UU perkawinan tidak membahas apakah laki-laki atau perempuan sejak lahir atau hasil operasi rekonstruksi jenis kelamin. Karena yang ditekankan ialah laki-laki dan perempuan, sehingga dimungkinkan bagi waria melakukan pencatatan pernikahan di Indonesia. Dengan catatan waria tersebut telah melakukan operasi rekonstruksi pada kelamin dan mendapatkan pengesahan perubahan dokumen yang sah dari negara apabila ingin menikah dengan laki-laki.

Pasal 64 Undang-Undang Nomor 23 Tahun 2006 Tentang Administrasi Kependudukan mengatur secara limitatif bahwa komponen yang terdapat dalam Kartu Tanda Penduduk adalah laki-laki atau perempuan yang merujuk pada jenis kelamin. Berdasarkan pada UU Adminduk dan dikaitkan dengan UU perkawinan, jika seorang yang melakukan perkawinan sesama gender dan hendak mencatatkan di pencatatan sipil indonesia, hal tersebut tidak 
dimungkinkan meskipun perkawinan itu sah secara hukum di negara pernikahan tersebut dilangsungkan. Dengan demikian tidak akan terjadi pencatatan sipil di indonesia, karena secara otomatis pernikahan tersebut tidak diakui sah secara hukum nasional. Hal tersebut dapat dianalisis pada Pasal 56 ayat (1) dan (2) UU Perkawinan, perkawinan adalah sah apabila dilakukan menurut hukum di negara dimana perkawinan itu dilangsungkan dan tidak melanggar UU perkawinan. Pasal 34 UU No. 23 Tahun 2006 juga mensyaratkan pencatatan perkawinan yang sah menurut peraturan perundang-undangan.

Pasal 13 Peraturan Pemerintah Nomor 54 Tahun 2007 Tentang Pelaksanaan Pengangkatan Anak mengatur salah satu syarat calon orang tua angkat adalah memiliki status menikah paling singkat 5 tahun dan bukan pasangan sejenis. Ketentuan ini mengakui adanya pasangan sesama gender yang dalam aturan ini dikecualikan untuk dapat menjadi orang tua angkat. Hingga kini praktek perkawinan sesama gender di Indonesia masih belum bisa dilakukan secara sah. Ketentuan tersebut dapat digunakan untuk membatasi calon orang tua angkat warga negara asing yang telah menikah secara sah dengan pasangan yang memiliki gender yang sama.

Salah satu peraturan kebijakan yang secara khusus melakukan diskriminasi terhadap identitas waria itu sendiri adalah Surat Edaran Komisi Penyiaran Indonesia Nomor: K/KPI/02/16. Tentang Edaran Kepada Seluruh Lembaga Penyiaran Mengenai Pria yang Kewanitaan. Surat edaran tersebut mengakui bahwa terdapat realitas ekspresi gender dimana pria memiliki sifat perempuan. Namun ekspresi gender seorang laki-laki yang feminin dilarang untuk disiarkan. Padahal ekspresi gender tidak berhubungan dengan identitas gender (Team, 2006). Oleh karena itu, seorang laki-laki yang memiliki sifat perempuan belum tentu memiliki identitas gender waria. Kendati tidak secara eksplisit menyebut waria namun klausula itu mendeskreditkan karakteristik identitas waria.

Peraturan Menteri Sosial Nomor 08 Tahun 2012 Tentang Pedoman Pendataan dan Pengelolaan Data Penyandang Masalah Kesejahteraan Sosial dan Potensi dan Sumber Kesejahteraan Sosial dalam lampirannya menggolongkan waria sebagai kelompok minoritas yang mengalami gangguan keberfungsian sosialnya akibat diskriminasi dan marginalisasi. Akan tetapi peraturan tersebut memberikan kriteria bahwa seorang waria memiliki perilaku seks menyimpang. Ketentuan ini memberikan pengakuan bahwa waria adalah kelompok minoritas yang rentan sekaligus mendiskriminasi karena dianggap menyimpang.

\section{Pengakuan Identitas Waria Dalam Kasus Waria Berhadapan Dengan Hukum}

Komunitas waria di Yogyakarta sudah sering berhadapan dengan polisi karena beberapa kali mendapatkan presekusi dari kelompok lain. Tahun 2012 organisasi masa Majelis Mujahidin Indonesia membubarkan dengan paksa diskusi buku karya Irsyad Mandji bersama penulisnya di kantor LKiS Yogyakarta (Rudiana, 2012). Diskusi buku tersebut juga dihadiri oleh anggota komunitas waria di Yogyakarta. Pada tahun 2013, seorang waria ditemukan meninggal di parit desa di daerah kabupaten Sleman. Waria tersebut disinyalir adalah korban pembunuhan karena terdapat bekas luka sayatan benda tajam (Kusuma, 2013). Tahun 2014 aksi hari peringatan transgender sedunia di kawasan Tugu Yogyakarta diserang. Beberapa waria yang mengikuti aksi tersebut dihadang dan dianiaya oleh sekelompok orang yang tidak dikenal (Kusuma, 2014). Pada tahun 2016, Pondok Pesantren Waria Al-Fatah didatangi oleh sekolompok orang dari organisasi masa Front Jihad Islam yang sebelumnya sudah beredar ancaman penyegelan pondok pesantren waria (Yuliawati, 2016). Di tahun yang sama, masa dari Forum Umat Islam menggelar aksi tandingan untuk 
menghadang aksi masa dari jaringan Solidaritas Perjuangan Demokrasi (Wicaksono, 2016). Solidaritas Perjuangan Demokrasi menggelar aksi dalam rangka merespon sayembara penolakan LGBT di Yogyakarta. Spanduk yang berisi ujaran homofobia dan transfobia sudah terpasang di beberapa sudut kota Yogyakarta. Dari banyaknya kasus presekusi dan kekerasan terhadap waria yang berlangsung di Yogyakarta tersebut belum ada yang diproses hingga putusan pengadilan.

Identitas waria di Yogyakarta sudah diperjuangkan cukup lama. Inisiasi pertama untuk melakukan pengorganisasian waria di Yogyakarta sudah dimulai sejak tahun1980 dengan berdirinya organisasi Waria DIY (Widayanti, 2009). Sejak itu dinamika pengorganisasian waria terus berkembang hingga kini dengan menghasilkan jaringan yang semakin solid dan terorganisir dengan baik. Bersama jaringan yang terlibat, waria kerap mengikuti pelatihan dan tampil di ruang-ruang publik. Oleh karena itu, waria di Yogyakarta sudah cukup terliterasi dengan wacana advokasi, termasuk advokasi waria yang berhadapan dengan hukum.

Dalam hukum acara pidana di Indonesia, konsep berhadapan dengan hukum hanya dikenal terhadap anak dan perempuan. Undang-Undang No 11 Tahun 2012 Tentang Sistem Peradilan Pidana Anak menjelaskan bahwa anak yang berhadapan dengan hukum adalah anak yang berkonflik dengan hukum (diduga melakukan tindak pidana), anak yang menjadi korban tindak pidana, dan anak yang menjadi saksi tindak pidana. Sementara Peraturan Mahkamah Agung Nomor 3 Tahun 2017 Tentang Pedoman Mengadili Perkara Perempuan Berhadapan Dengan Hukum menjelaskan bahwa perempuan berhadapan dengan hukum adalah perempuan yang berkonflik dengan hukum, perempuan sebagai korban, perempuan sebagai saksi atau perempuan sebagai pihak.

Dalam Perma No. 3 Tahun 2017 sudah mengenal konsep kesetaraan gender. Kendati demikian kesetaraan gender yang dimaksud hanya mengakui identitas gender laki-laki dan perempuan. Sementara identitas gender yang lain, yang tidak memenuhi standar biner laki-laki dan perempuan, belum mendapatkan pengakuan. Pasal 1 angka 1 Perma No. 3 Tahun 2017 menyebutkan "Kesetaraan Gender adalah kesamaan dan keseimbangan kondisi antara laki-laki dan perempuan untuk memperoleh kesempatan dan hak-haknya sebagai manusia agar mampu berperan dan berpartisipasi di berbagai bidang."

Kasus berhadapan dengan hukum yang kerap dialami waria di Yogyakarta adalah terjarirng penertiban satuan polisi pamong praja. Penertiban oleh Satpol PP maupun Penyidik Pegawai Negeri Sipil (PPNS) terhadap waria didominasi oleh kasus pengamenan di jalan. Ada banyak faktor yang menyebabkan waria di yogyakarta memutuskan mencari uang sebagai pengamen di jalan, antara lain : wadah pemberontakan struktur sosial yang memarjinalkan waria, minimnya akses lapangan kerja, pendidikan rendah, dan adanya diskriminasi dalam kehidupan sosial (Sa'dan, 2018).

Pasca diterbitkannya Peraturan Daerah Daerah Istimewa Yogyakarta Nomor 1 Tahun 2014 Tentang Penanganan Gelandangan dan Pengemis, penertiban waria yang mengamen di jalan mulai dilakukan pemerintah daerah. Perda DIY No. 1 Tahun 2014 melakukan kriminalisasi terhadap perbuatan pengemisan dimana mengamen menurut Perda a quo termasuk dalam pengemisan. Pasal 1 angka 6 Perda DIY menyebutkan bahwa "Pengemisan adalah tindakan meminta-minta yang dilakukan oleh individudan/atau sekelompok orang dengan berbagai alasan, cara dan alat untuk mengharapkan belas kasihan dari orang lain."

Kasus waria yang terkena razia oleh Satpol PP biasanya diadvokasi oleh internal organisasi waria. Anggota komunitas waria sudah kerap beinteraksi dengan petugas dinas sosial dalam melakukan advokasi waria yang terkena penertiban Satpol PP. Menurut pengakuan waria yang pernah terkena razia satpol $\mathrm{PP}$, ia merasa 
diperlakukan baik oleh petugas. Petugas menyapa waria tersebut dengan sebutan "mbak" dan tidak mendapatkan kekerasan karena identitasnya sebagai waria.

Kendati demikian, terdapat kasus waria yang berhadapan dengan Satpol PP yang didampingi oleh Lembaga Bantuan Hukum Yogyakarta. Salah satunya yang terjadi di tahun 2020 di daerah kabupaten Kulon Progo. Kasus itu bermula dari aktivitas waria di kulon progo yang membuka usaha kelontong. Satpol PP melakukan penertiban karena ada laporan dari masyarakat atas dugaan pelanggaran kesusilaan (prostitusi) di tempat usaha tersebut. Dalam forum audiensi bersama LBH Yogyakarta, Satpol PP menyebut waria yang beraktivias tersebut telah menistakan agama karena mengenakan jilbab.

Di tahun 2016 terdapat sebuah kasus kekerasan fisik terhadap waria. Pada saat itu, korban sedang berjalan bersama temannya pada malam hari. Tiba-tiba ada seorang pria yang memukul korban dengan kursi plastik. Korban langsung melaporkan peristiwa itu ke kantor polisi. Di kantor polisi korban diminta untuk mengeluarkn KTP. Kendati mengetahui korban adalah waria, polisi tetap memperlakukan waria tersebut dengan baik. Laporan yang ia ajukan direspon dan diproses. Korban diantar oleh polisi untuk melakukan visum. Polisi menyebut korban dengan panggilan "mbak".

Dari hasil wawancara dengan waria yang berkonflik dengan hukum juga didapat bahwa waria diperlakukan baik oleh aparat penegak hukum. Dari hasil wawancara dengan penyintas diketahui bahwa waria tersebut merasa diperlakukan baik kendati aparat penegak hukum mengetahui identitas gendernya sebagai waria. Sebelum dipindah ke Lembaga Pemasyarakatan (Lapas), ia ditempatkan di tahanan laki-laki di kantor polisi. Di lembaga pemasyarakatan ia dipanggil dengan panggilan "bunda". Pada saat di persidangan ia dipanggil dengan panggilan "bunda" baru kemudian diikuti nama alias yaitu nama asli waria tersebut. Meskipun dalam sistem peradilan pidana tidak mengenal adanya identitas waria, namun dalam prakteknya aparat penegak hukum mengakui bahwa ia adalah waria.

Kemudian dari hasil wawancara dengan waria yang menjadi saksi atau pendamping dalam kasus waria berhadapan dengan hukum, diketahui bahwa di beberapa kesempatan aparat penegak hukum masih belum paham dengan masalah waria. Hal itu dapat dilihat dari pernyataan penegak hukum yang mempertanyakan apakah waria laki-laki atau perempuan. Di persidangan, narasumber yang menjadi saksi kendati sudah berpenampilan sebagai perempuan, tetap dipanggil "pak". Di beberapa kesempatan, waria yang diperiksa ada yang dipanggil "pak". Namun setelah diberikan edukasi, maka aparat penegak hukum menyebut waria tersebut dengan sebutan perempuan. Di lapas, ketika ada waria yang ingin menjenguk warga binaan lapas, petugas sempat mengalami kebingungan untuk pemeriksaan badan. Pada mulanya waria yang mengunjungi lapas diperiksa oleh laki-laki. Namun dalam kasus tersebut, setelah ada yang protes, kemudian waria dipersilahkan untuk bebas memilih diperiksa oleh petugas laki-laki atau perempuan.

\section{Simpulan}

Pengakuan identitas waria dapat dilihat dari pengakuan keragaman identitas gender dan orientasi seks yang diatur dalam ICCPR dan ICESR yang telah diratifikasi Indonesia. Dalam hukum Indonesia, ICCPR dan ICESR baru ditranformasikan secara formal. Akan tetapi dalam hal waria yang berhadapan dengan hukum, Indonesia belum melakukan tranformasi secara subtansial berkaitan dengan pengakuan keragaman orientasi seks dan identitas gender. Dalam peraturan perundang-undangan nasional Indonesia, identitas dan karakteristik waria diakui sebagai penyimpangan.

Dalam beberapa kasus waria yang berhadapan dengan hukum, waria sudah diterima identitas dan karakteristiknya oleh aparat penegak hukum meskipun belum sepenuhnya. Hal itu terlihat dari keterangan para narasumber yang merasa diperlakukan baik dan dipanggil dengan salutasi yang 
mereka inginkan. Beberapa kasus menunjukan terdapat aparat penegak hukum yang tidak paham konsep identitas dan karakteristik waria. Meskipun demikian, aparat penegak hukum bersedia untuk mengubah cara memperlakukan waria setelah diberikan pemahaman oleh pendamping hukum.

\section{DAFTAR PUSTAKA}

Amali, Z. (2020). Kasus Mira: Kejanggalan Penyidikan Polisi. Transpuan Berhak Hidup. - Tirto.ID. Diambil 27 September 2020, dari https://tirto.id/kasus-mira-kejanggalanpenyidikan-polisi-transpuan-berhakhidup-eL8r

Blackwood, E. (2005). Transnational sexualities in one place: Indonesian readings. Gender and Society, 19(2), 221-242.

https://doi.org/10.1177/0891243204272 862

Blackwood, E., \& Johnson, M. (2012). Queer Asian Subjects: Transgressive Sexualities and Heteronormative Meanings. Asian Studies Review, 36(4), 441-451.

https://doi.org/10.1080/10357823.2012. 741037

Boellstorff, T. (2004). Playing back the nation: Waria, Indonesian transvestites. Cultural Anthropology, 19(2), 159-195. https://doi.org/10.1525/can.2004.19.2.1 59

BPHN. (2015). Draft Naskah Akademik Rancangan Undang-Undang Hukum Pidana(KUHP) Badan Pembinaan Hukum Nasional.

Briantika, A. (2020). Bingung Kelamin Lucinta Luna, Polisi Pilih Tempatkan di Sel Khusus - Tirto.ID. Diambil 27 September 2020, dari https://irto.id/bingung-kelamin-lucintaluna-polisi-pilih-tempatkan-di-selkhusus-eyue
Kusuma, W. (2013, Februari 28). Waria Dibunuh, Ikatan Waria Yogya Datangi Mapolda. Diambil 30 September 2020, dari

https://regional.kompas.com/read/2013/ 02/28/16421478/Waria.Dibunuh.Ikatan. Waria.Yogya.Datangi.Mapolda.

Kusuma, W. (2014, November 21). Enam Peserta Aksi "Transgender Day" Diserang Orang Tak Dikenal. Diambil 30 September 2020, dari https://regional.kompas.com/read/2014/ 11/21/13434181/Enam.Peserta.Aksi.Tra nsgender.Day.Diserang.Orang.Tak.Dike nal

Muthmainnah, Y. (2015). Hak Asasi Manusia LGBT dalam Kebijakan Dalam Negeri Indonesia. Jurnal Perempuan, 20 No. 4(Keragaman Gender dan Seksualitas).

O'Flaherty, M. (2015). The Yogyakarta Principles at Ten. Nordic Journal of Human Rights, 33(4), 280-298. https://doi.org/10.1080/18918131.2015. 1127009

Petrova, D. (2013). The use of equality and anti discrimination law in advancing LGBT rights. In C. Lennox \& $\mathrm{M}$. Waites (Ed.), Human Rights, Sexual Orientation and Gender Identity in the Comonwealth (hal. 477-501).

Pinel, J. (2009). Edisi Ketujuh Biopsikologi (bahasa ind; H. Soetjipto \& S. Soetjipto, Ed.). Yogyakarta: Pustaka Pelajar.

Rudiana, P. A. (2012). Diskusi Irshad Manji Bubar Karena Diserang MMI Nasional Tempo.co. Diambil 30 September 2020, dari https://nasional.tempo.co/read/402826/d iskusi-irshad-manji-bubar-karenadiserangmmi

Sa'dan, M. (2018). Waria, Pemerintah, Dan Hak Seksual: Kasus Implementasi Perda Gepeng Di Daerah Istimewa Yogyakarta. NALAR: Jurnal Peradaban dan Pemikiran Islam, 1(2), 124. 
https://doi.org/10.23971/njppi.v1i2.908

Sefriani. (2010). Hukum Internasional: Suatu Pengantar. Jakarta: Rajawali Pers.

Team, Y. P. (2006). The Yogyakarta Principles.

Wicaksono, P. (2016). Massa FUI Hadang Demo Pendukung LGBT di Tugu Yogya - Nasional Tempo.co. Diambil 30 September 2020, dari https://nasional.tempo.co/read/747549/ massa-fui-hadang-demo-pendukunglgbt-di-tugu-yogya/full\&view $=$ ok
Widayanti, T. (2009). Politik Subaltern Pergulatan Identitas Waria. Yogyakarta: Research Center for Politicts and Government Jurusan Politik dan Pemerintahan UGM.

Yuliawati. (2016, Februari 19). Pondok Pesantren Waria di Yogyakarta Mendapat Ancaman. Diambil 30 September 2020, dari https://www.cnnindonesia.com/nasional /20160219192701-12-112171/pondokpesantren-waria-di-yogyakartamendapat-ancaman 